\title{
Perancangan Jaringan Indoor 4G LTE 1800 MHz Gedung Elektronika Politeknik Negeri Balikpapan Menggunakan Radiowave Propagation Simulator 5.4
}

\author{
Maria Ulfah ${ }^{1}$, Nelsia Pither Tadung ${ }^{2}$ \\ 1,2 Jurusan Teknik Elektronika, Politeknik Negeri Balikpapan \\ ${ }^{1}$ maria.ulfah@poltekba.ac.id
}

\begin{abstract}
Indoor area is an area that lacks a signal so that the signal attenuation continues to be problems that often occur. To overcome these problems need the support of a communication system that can include a signal in the room so that customers can keep communicate with smoothly. The need for application of Indoor mobile communications system to support the outdoor system that can serve the entire mobile service users. This research discusses the planning of Indoor femtocell LTE 4G network at the electronics building of the Balikpapan State Polytechnic is on the floor 1,2 and 3 with models Cost 231 multiwall Indoor propagation. This design is simulated using 5.4 Software Radiowave Propagation Simulator (RPS). From the calculation results, the number of Femtocell Access Points (FAP) on each floor is 3, the placement of FAP in the middle part of each floor of the Electronics building. From the design results obtained on the 1st floor RSRP value of $-32.18 \mathrm{dBm}$ and SIR of $12.31 \mathrm{~dB}$, for floors $2 \mathrm{RSRP}-34.20 \mathrm{dBm}$ and SIR of $13.52 \mathrm{~dB}$, and floor 3 RSRP value of $-33.32 \mathrm{dBm}$ and SIR is $13.27 \mathrm{~dB}$
\end{abstract}

Keywords : Femtocell, Radiowave Propagation Simulator, Indoor, Cost 231

\section{INTISARI}

Area indoor merupakan area yang kurang mendapatkan sinyal sehingga pelemahan sinyal terus menjadi permasalahan yang sering terjadi. Untuk mengatasi permasalahan tersebut perlu adanya dukungan sistem komunikasi yang dapat mencakup sinyal didalam ruangan agar pelanggan dapat tetap berkomunikasi dengan lancar. Perlunya penerapan sistem komunikasi seluler indoor dilakukan untuk mendukung sistem outdoor sehingga layanan seluler dapat melayani seluruh user.Penelitian ini membahas perancangan jaringan indoor femtocell 4G LTE pada gedung Elektronika Politeknik Negeri Balikpapan pada lantai 1,2 dan 3 dengan model propagasi Cost 231 multiwall Indoor. Perancangan ini disimulasikan dengan menggunakan software Radiowave Propagation Simulator 5.4 (RPS). Dari hasil perhitungan didapatkan jumlah Femtocell Access Point (FAP) pada setiap lantainya sebanyak 3 buah, penempatan FAP di bagian tengah di setiap lantai gedung Elektronika. Dari hasil perancangan didapatkan pada lantai 1 nilai RSRP -32,18 dBm dan SIR sebesar 12,31 dB, untuk lantai 2 RSRP -34,20 dBm dan SIR sebesar 13,52 dB, dan lantai 3 nilai RSRP -33,32 dBm dan SIR sebesar 13,27 dB.

Kata kunci: Femtocell, Radiowave Propagation Simulator, Indoor, Cost 231

\section{PENDAHULUAN}

Seiring perkembangan zaman, perkembangan teknologi juga terus berkembang salah satunya teknologi telekomunikasi yang saat ini sudah menuju teknologi broadband wireless access, hal ini menjadi tuntutan tersendiri bagi user untuk dapat memenuhi komunikasi dengan laju data yang tinggi, kapasitas yang besar, area akses yang semakin luas dan mobilitas yang tinggi dimanapun user berada baik di dalam gedung (indoor) maupun di luar gedung (outdoor).
Hadirnya jaringan 4G (LTE) merupakan Service yang dikehendaki oleh user yaitu sistem komunikasi berbasis kecepatan tinggi yang memiliki kapasitas dan data rate yang tinggi. Namun kapasitas yang tinggi ini kurang dirasakan jika user berada di dalam area gedung (indoor) hal ini terjadi karena adanya proses redaman terhadap sinyal telekomunikasi sehingga komunikasi yang diharapkan handal akan tetap mengalami gangguan. Contohnya pada sebuah ruangan dalam gedung bertingkat yang tidak dapat dijangkau oleh jaringan 
Jurnal ECOTIPE, Volume 6, No.1, April 2019, Hal. 40-48

p-ISSN 2355-5068, e-ISSN 2622-4852

DOI: 10.33019/ecotipe.v6i1.950

outdoor. Penyedia layanan komunikasi harus melakukan peningkatan terhadap kemampuan jaringan salah satu dengan melakukan pembangunan jaringan pada area dalam gedung (indoor networking) dengan menggunakan femtocell untuk jaringan LTE. Femtocell atau Home Node B adalah teknologi pemancar mikro yang menggunakan level daya rendah dan memiliki cakupan yang lebih kecil dibandingkan dengan BTS. Penerapan LTE dilakukan melalui teknik Indoor penetration yakni dengan cara menghubungkan Femtocell Access Point (FAP) ke jaringan internet yang menggunakan link jaringan akses data dan terhubung ke jaringan dari provider yang bersangkutan. Berdasarkan latar belakang tersebut maka perlu dilakukan perancangan dan analisa jaringan Indoor 4G LTE pada gedung elektronika Politeknik Negeri Balikpapan dengan menggunakan Radiowave Propagation Simulator 5.4.

\section{LANDASAN TEORI}

\section{A. Perkembangan Teknologi Jaringan Seluler}

Dalam perkembangan sekarang ini piranti ini mengalami banyak perkembangan, dari sekedar alat komunikasi analog sekarang telah berubah menjadi alat komunikasi digital yang bisa mentransmisikan bukan voice saja akan tetapi telah merambah kepada transmisi data seperti sms, mms, bahkan mengunduh data ataupun mengakses data dari internet dan terus bertumbuh baik dari segi kecepatan maupun kualitas multimedia, transfer data, smart sync, dan lain lain untuk menunjang mobilitas itu sendiri, mulai dari generasi pertama (1 G), generasi kedua (2 G), generasi ketiga ( $3 \mathrm{G})$.

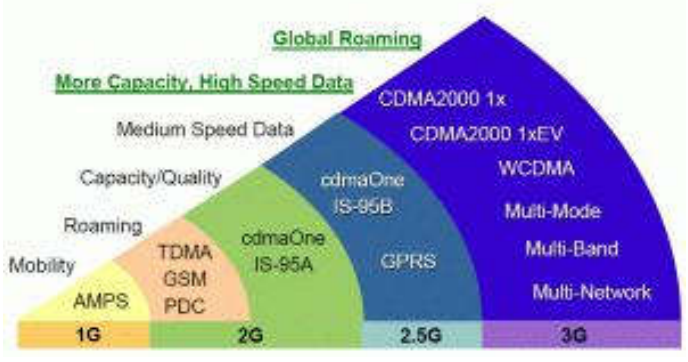

Gambar 1. Perkembangan Teknologi Seluler [1]

Teknologi seluler mengalami perkembangan ke generasi keempat (4G) antara lain Long Term Evolution (LTE) yang merupakan jaringan akses radio evolusi jangka panjang keluaran dari $3^{\text {rd }}$ Generation Partership Project (GPP). LTE merupakan kelanjutan dari teknologi generasi ketiga (3G) WDCMA-UMTS.

Pada LTE kecepatan transfer data mencapai $100 \mathrm{Mbps}$ pada sisi downlink dan 50Mbps pada sisi uplink. Berikut adalah gambar yang menunjukkan perkembangan 3GPP dari release 99 hingga release 8. [2]

\section{B. Arsitektur Jaringan $4 G$ LTE}

Berikut arsitektur jaringan 4G LTE.

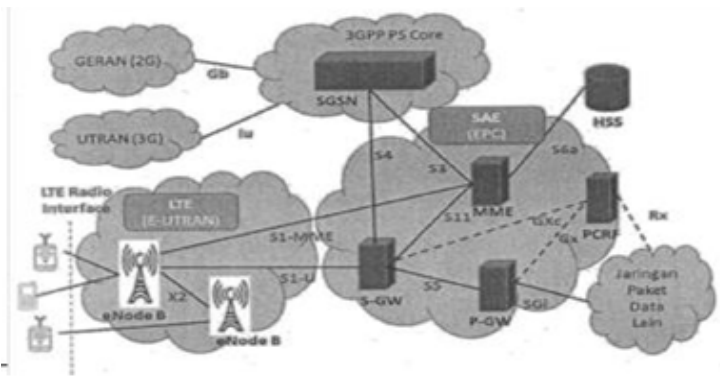

Gambar 2. Arsitektur 4G LTE

Arsitektur LTE [3] terdiri atas dua bagian utama yakni LTE itu sendiri yang dikenal juga dengan E-UTRAN (Envolved Universal Terrestrial Radio Access Network) dan SAE (System Architecture Evolution) yang merupakan jantung dari sistem. [3]

\section{Konsep Dasar Femtocell}

Femtocell merupakan teknologi pemancar mikro atau juga dapat disebut dengan Home 
Base Station yang menggunakan level daya rendah yang berfungsi untuk memperluas cakupan dan meningkatkan kapasitas. Femtocell merupakan access point nirkabel dengan berdaya rendah yang menggunakan spektrum frekuensi berlisensi saat beroperasi. Dengan kata lain, femtocell dapat didefinisikan sebagai Base Transceiver Station (BTS) yang berukuran mini dengan ditempatkan di wilayah yang bersinyal rendah, sehingga dapat meningkatkan ketersediaan, konektivitas, mobilitas, serta kinerja layanan jaringan dengan kebutuhan daya yang rendah. Femtocell dapat dijadikan sebagai solusi dari keterbatasan jaringan Base Transceiver Station (BTS) yang tidak dapat menjangkau user yang berada di area Indoor. [4]

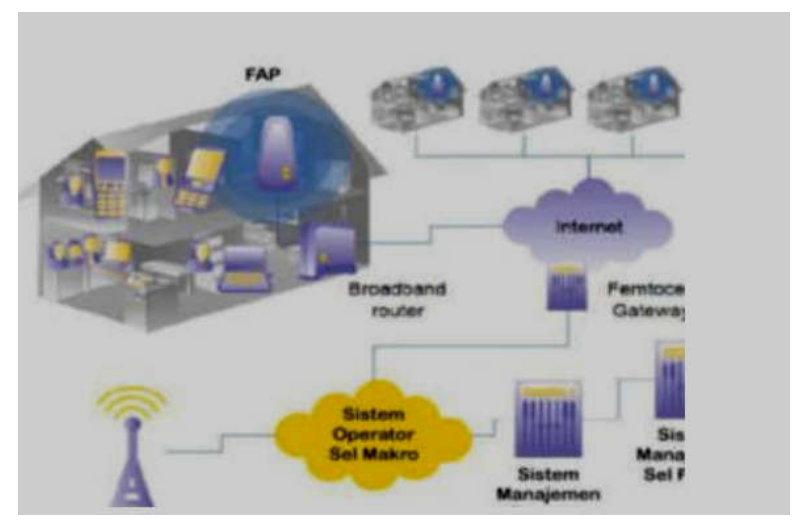

Gambar 3. Penggunaan Femtocell

\section{COST 231 Multi-Wall Model}

Pada model propagasi COST 231 Multi-Wall seluruh dinding pada bidang vertikal antara transmitter dengan receiver akan dipertimbangkan, Sedangkan untuk masingmasing dinding dengan properties materialnya diperhitungkan juga, bertambahnya dinding yang akan dilewati sinyal akan membuat attenuasi dinding menjadi berkurang sehingga pada model COST 231 MWM ini hasil yang didapatkan akan sesuai dengan kondisi ruangan. [5]

\section{E. Parameter Kinerja Jaringan $4 G$ LTE}

\section{Reference Signal Received Power (RSRP)}

Nilai RSRP merupakan power sinyal reference yang digunakan untuk menunjukkan bagus tidaknya coverage jaringan pada suatu daerah.

Tabel 1. Rentang Nilai RSRP [6]

\begin{tabular}{|c|l|}
\hline Nilai & \multicolumn{1}{|c|}{ Keterangan } \\
\hline$-10--45 \mathrm{dBm}$ & Sangat Baik \\
\hline$-46--70 \mathrm{dBm}$ & Baik \\
\hline$-71--90 \mathrm{dBm}$ & Cukup \\
\hline$-91-110 \mathrm{dBm}$ & Buruk \\
\hline
\end{tabular}

\section{Signal to Interference Ratio (SIR)}

Signal to Interference Ratio (SIR) merupakan perbandingan kuat sinyal dibanding interferensi sinyal dari sel lain. Parameter ini menunjukkan level daya minimum dimana user masih bisa melakukan suatu panggilan

Tabel 2. Rentang Nilai SIR [7]

\begin{tabular}{|c|l|}
\hline Nilai & Keterangan \\
\hline$<20 \mathrm{~dB}$ & Sangat Baik \\
\hline $19-8 \mathrm{~dB}$ & Baik \\
\hline $8-0 \mathrm{~dB}$ & Cukup \\
\hline$>0 \mathrm{~dB}$ & Buruk \\
\hline
\end{tabular}

\section{METODE PENELITIAN}

\section{A. Rancangan Penelitian}

Rancangan penelitian merupakan keseluruhan proses penelitian dari awal hingga tahap akhir, dan disajikan dalam bentuk flowchart berikut ini: 


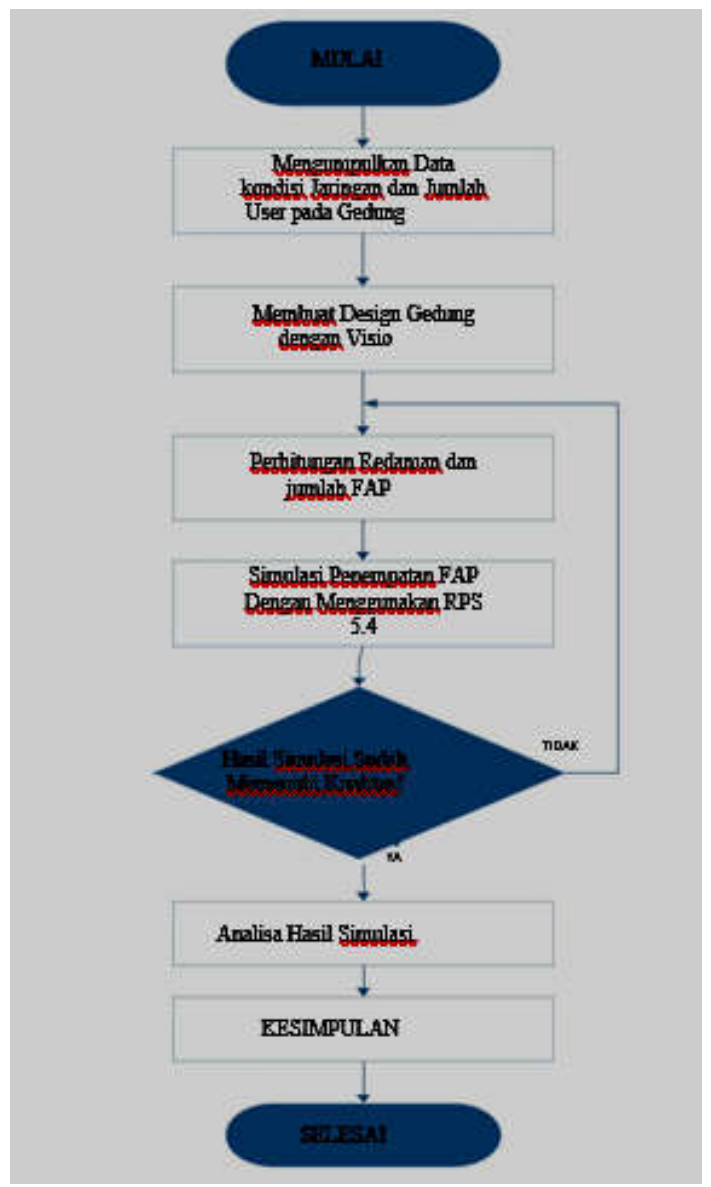

Gambar 3. Flowchart

\section{B. Teknik Pengumpulan dan Analisis Data}

Teknik Pengumpulan data dilakukan dengan mempelajari kondisi jaringan 4G LTE yang ada di gedung Elektronika, dilanjutkan dengan mengumpulkan informasi jumlah penggunan jaringan 4G LTE yang ada di gedung tersebut. Kemudian membuat desain gedung di MS Visio, menghitung redaman pada arah uplink dan downlink dan jumlah Femtocell yang dibutuhkan untuk melayani kebutuhan jaringan $4 \mathrm{G}$ LTE indoor gedung Elektronika. Melakukan simulasi perancangan jaringan Indoor 4G LTE memakai Software Radiowave Propagation Simulator (RPS) 5.4 . Melakukan Analisa apakah hasil perancangan di atas telah memenuhi kriteria parameter perfomansi jaringan yakni RSRP dan SIR. Kemudian dilanjutkan membuat kesimpulan terhadap hasil perancangan jaringan tersebut.

\section{HASIL DAN PEMBAHASAN}

Perhitungan pada perencanaan jaringan indoor tersebut menggunakan persamaan Cost 231 Multiwall Model. Hasil yang diperoleh berdasarkan simulasi menggunakan Radiowave Propagation Simulator (RPS) didapatkan grafik yang menunjukan nilai dari coverage.

\section{A. Perhitungan Link Budget}

Perhitungan link budget dilakukan untuk menghitung area cakupan sel dengan mengetahui nilai Maximum Allowable Path Loss (MAPL) dalam sistem agar saling berkomunikasi. Link budget merupakan perhitungan sejumlah daya yang didapat oleh penerima berdasarkan daya keluaran dari pemancar dengan mempertimbangkan gain dan loss sepanjang jalur transmisi radio dari pemancar ke penerima.

\begin{tabular}{|c|c|c|c|}
\hline \multicolumn{3}{|c|}{ Transmitter (Mobile station) } & \\
\hline & Item & Rumus & \\
\hline a & $\begin{array}{l}\text { Maximum mobile Tx } \\
\text { power }(\mathrm{dBm})\end{array}$ & & 20 \\
\hline $\mathrm{b}$ & Mobile antenna gain & & 0 \\
\hline c & Body/orientation loss & & 0 \\
\hline d & $\operatorname{EIRP}(\mathrm{dBm})$ & $(d=a+b+c)$ & 20 \\
\hline \multicolumn{4}{|c|}{ Receiver (Mobile Station) } \\
\hline e & $\begin{array}{l}\text { Thermal noise density } \\
(\mathrm{dBm} / \mathrm{Hz})\end{array}$ & $\begin{array}{l}\mathrm{KTB}=\left(1,38 \times 10^{-25} \times 290\right)=-249 \\
\mathrm{dBW}=-174\end{array}$ & .174 \\
\hline$f$ & $\begin{array}{l}\text { MS receiver noise figure } \\
(\mathrm{dB})\end{array}$ & & 4 \\
\hline$g$ & $\begin{array}{l}\text { Receiver noise density } \\
(\mathrm{dBm} / \mathrm{Hz})\end{array}$ & $(g=e+f)$ & -170 \\
\hline $\mathrm{h}$ & $\begin{array}{l}\text { Receiver noise Power } \\
(\mathrm{dBm})\end{array}$ & $\left(\mathrm{h}=\mathrm{g}+10 \log \left(14,4 \times 10^{-0}\right)\right)$ & $-214,42$ \\
\hline$i$ & Interface margin $(\mathrm{dB})$ & & 2 \\
\hline j & $\begin{array}{ll}\text { Noise \& interference } \\
(\mathrm{dBm})\end{array}$ & $(j=h+j)$ & $.212,42$ \\
\hline $\mathrm{k}$ & Processing gain $(\mathrm{dB})$ & $(\mathrm{k}=10 \log (14,4 \mathrm{Mbps} / 384))$ & 14,2 \\
\hline 1 & \begin{tabular}{|l|l} 
Required $\mathrm{Eb} / \mathrm{No}_{0}$ \\
\end{tabular} & Data $384 \mathrm{kbps}$ & 2 \\
\hline $\mathrm{m}$ & \begin{tabular}{|ll}
$\begin{array}{l}\text { Receiver } \\
(\mathrm{dBm})\end{array}$ & sensitivity \\
\end{tabular} & $(m=1-k+j)$ & $.200,22$ \\
\hline n & Base station antena gain & & 0 \\
\hline 0 & Fast fading margin & & 1 \\
\hline$p$ & Maximun path loss $(\mathrm{dB})$ & $(q=d-m+n-0)$ & 201,22 \\
\hline
\end{tabular}

Gambar 4. MAPL Arah Downlink 


\begin{tabular}{|c|c|c|c|}
\hline \multicolumn{3}{|c|}{ Transmitter (Mobile station) } & \\
\hline & Item & Rumus & \\
\hline a & $\begin{array}{l}\text { Maximum mobile } \mathrm{Tx} \\
\text { power }(\mathrm{dBm})\end{array}$ & & 20 \\
\hline $\mathrm{b}$ & Mobile antenna gain & & 0 \\
\hline c & Body/orientation loss & & 0 \\
\hline $\mathrm{d}$ & $\operatorname{EIRP}(\mathrm{dBm})$ & $(d=a+b+c)$ & 20 \\
\hline \multicolumn{4}{|c|}{ Receiver (Mobile Station) } \\
\hline $\mathrm{e}$ & $\begin{array}{l}\text { Thermal noise density } \\
(\mathrm{dBm} / \mathrm{Hz})\end{array}$ & $\begin{array}{l}\text { KTB }=\left(1,38 \times 10^{-23} \times 290\right)=-249 \\
\text { dBW }=-174\end{array}$ & -174 \\
\hline$f$ & $\begin{array}{l}\text { MS receiver noise figure } \\
(\mathrm{dB})\end{array}$ & & 4 \\
\hline g & $\begin{array}{l}\text { Receiver noise density } \\
(\mathrm{dBm} / \mathrm{Hz})\end{array}$ & $(g=e+f)$ & -170 \\
\hline $\mathrm{h}$ & \begin{tabular}{|l}
$\begin{array}{l}\text { Receiver noise Power } \\
(\mathrm{dBm})\end{array}$ \\
\end{tabular} & $\left(\mathrm{h}=\mathrm{g}+10 \log \left(14,4 \mathrm{x} 10^{-6}\right)\right)$ & $-214,42$ \\
\hline i & Interface margin $(\mathrm{dB})$ & & 2 \\
\hline $\mathrm{j}$ & \begin{tabular}{|ll}
$\begin{array}{l}\text { Noise \& interference } \\
(\mathrm{dBm})\end{array}$ & \\
\end{tabular} & $(j=h+i)$ & $-212,42$ \\
\hline $\mathrm{k}$ & Processing gain $(\mathrm{dB})$ & $(\mathrm{k}=10 \log (14,4 \mathrm{Mbps} / 384))$ & 14,2 \\
\hline 1 & Required $\mathrm{Eb} / \mathrm{No}$ & Data $384 \mathrm{kbps}$ & 2 \\
\hline $\mathrm{m}$ & \begin{tabular}{|ll}
$\begin{array}{l}\text { Receiver sensitivity } \\
(\mathrm{dBm})\end{array}$ \\
\end{tabular} & $(m=1-k+j)$ & $-200,22$ \\
\hline $\mathrm{n}$ & Base station antena gain & & 0 \\
\hline 0 & Fast fading margin & & 1 \\
\hline$p$ & Maximun path loss $(\mathrm{dB})$ & $(q=d-m+n-0)$ & 201,22 \\
\hline
\end{tabular}

Gambar 5. MAPL Arah Uplink

Dari hasil perhitungan Link Budget yaitu MAPL dari arah uplink sebesar 201,12 dB dan dari arah downlink sebesar 202,72 dB dapat dihitung selisi diantaranya yaitu sebesar 1,6 dB .Maka hasil perencanan ini layak untuk diterapkan pada setiap lantai gedung Elektronika karena hasil perhitunggan tidak lebih dari $5 \mathrm{~dB}$.

\section{B. Perhitungan Jumlah FAP}

Dalam perhitungan FAP dalam penelitian ini yaitu menggunakan kapasitas user dimana asumsi user yang aktif pada setiap lantai adalah $60 \%$ dari jumlah user perlantainya.

Untuk menentukan jumlah Femtocell Access Point (FAP) yang dibutuhkan pada perancangan ini digunakan analisis berdasarkan kapasitas dengan menggunakan rumus berikut:

$$
\text { Jumlah FAP }=\frac{\text { Jumlah User }}{\text { Jumlah user tiap sel }}
$$

Tabel 3. Data user Gedung Elektronika

\begin{tabular}{|c|c|c|c|}
\hline No & $\begin{array}{c}\text { Gedung } \\
\text { Elektronika }\end{array}$ & $\begin{array}{c}\text { Jumlah } \\
\text { User }\end{array}$ & $\begin{array}{c}\text { Jumlah } \\
\text { FAP }\end{array}$ \\
\hline 1 & Lantai 1 & 203 & 3 \\
\hline 2 & Lantai 2 & 157 & 3 \\
\hline 3 & Lantai 3 & 132 & 3 \\
\hline
\end{tabular}

\section{Analisis Simulasi Radiowave Propagation Simulator (RPS)}

Hasil perhitungan dengan kapasitas yang telah didapatkan selanjutnya akan disimulasikan menggunakan Radiowave Propagation Simulator. Jumlah Femtocell Access Point (FAP) yang didapatkan dari perhitungan ialah berjumlah 3 FAP. FAP tersebut kemudian akan diimplementasikan di ketiga lantai dengan pemilihan penempatan FAP pada bagian sisi tengah gedung Elektronika.

1. Hasil Simulasi Lantai 1

Hasil simulasi dengan pemilihan penempatan FAP pada bagian tengah gedung terlihat pada Gambar 6.

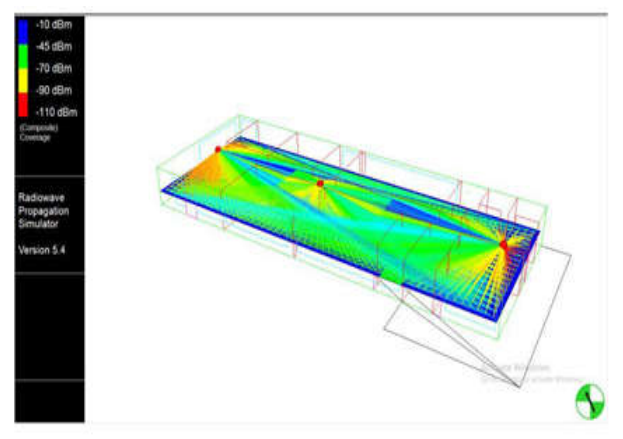

Gambar 6a. Tampilan coverage RSRP

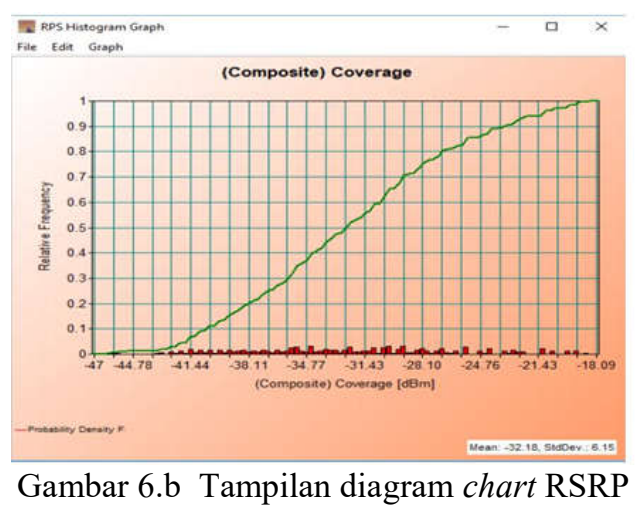


Jurnal ECOTIPE, Volume 6, No.1, April 2019, Hal. 40-48

p-ISSN 2355-5068, e-ISSN 2622-4852

DOI: 10.33019/ecotipe.v6i1.950

Dari hasil simulasi terlihat coverage RSRP menghasilkan mean -32,18 dBm. Hasil ini masuk dalam kategori sangat baik yaitu antara $-10 \mathrm{dBm}$ sampai $-45 \mathrm{dBm}$.

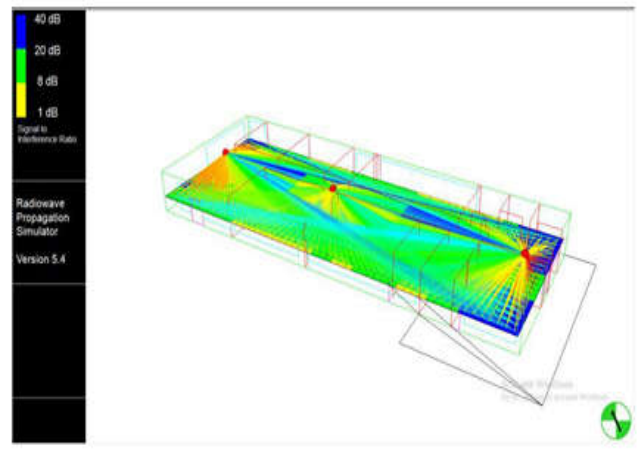

Gambar 6.c Tampilan coverage SIR

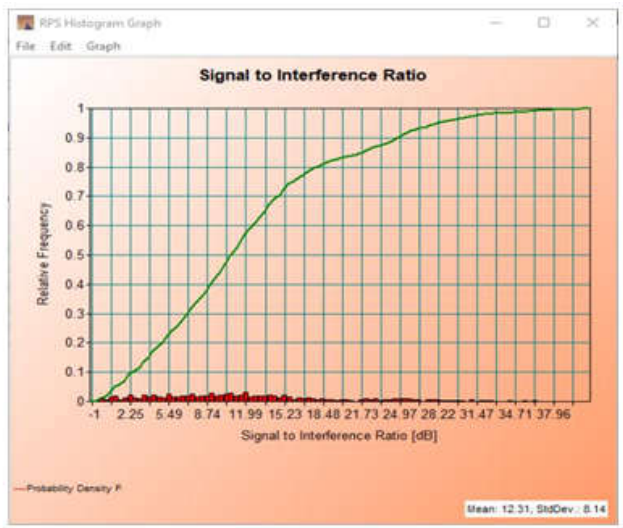

Gambar 6.d Tampilan diagram chart SIR

Sedangkan untuk hasil coverage SIR menghasilkan mean 12,31 dB . Hasil ini masuk dalam kategori baik yaitu antara $9 \mathrm{~dB}-20 \mathrm{~dB}$.

2. Hasil Simulasi Lantai 2

Hasil simulasi dengan pemilihan penempatan FAP pada bagian tengah gedung terlihat pada Gambar 7.
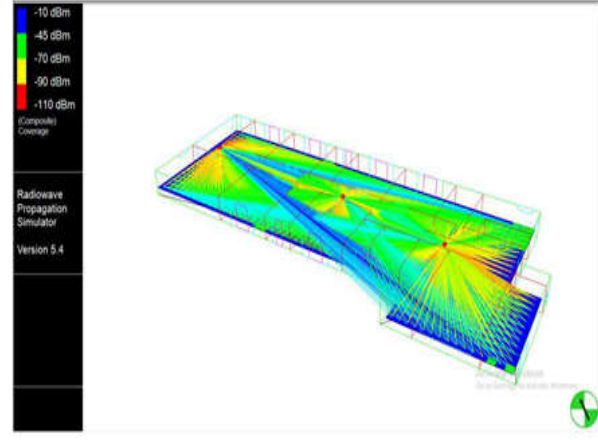

Gambar 7a. Tampilan coverage RSRP

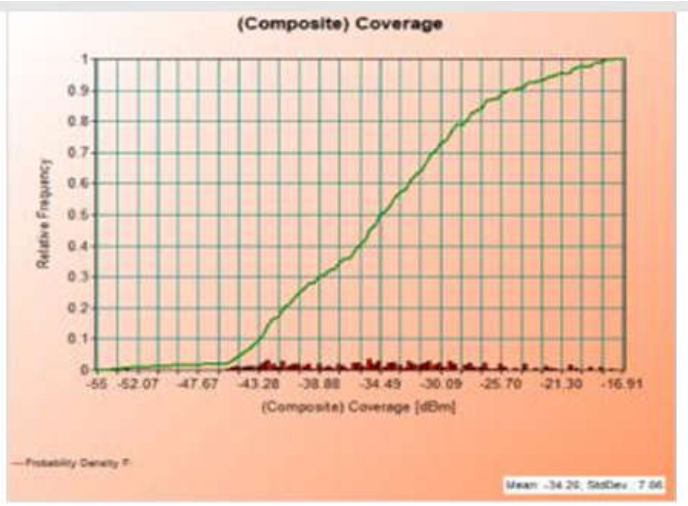

Gambar 7.b Tampilan diagram chart RSRP

Pada skenario ini coverage RSRP menghasilkan mean -34,20 dBm. Hasil ini masuk dalam kategori sangat baik yaitu antara $-10 \mathrm{dBm}$ sampai $-45 \mathrm{dBm}$.

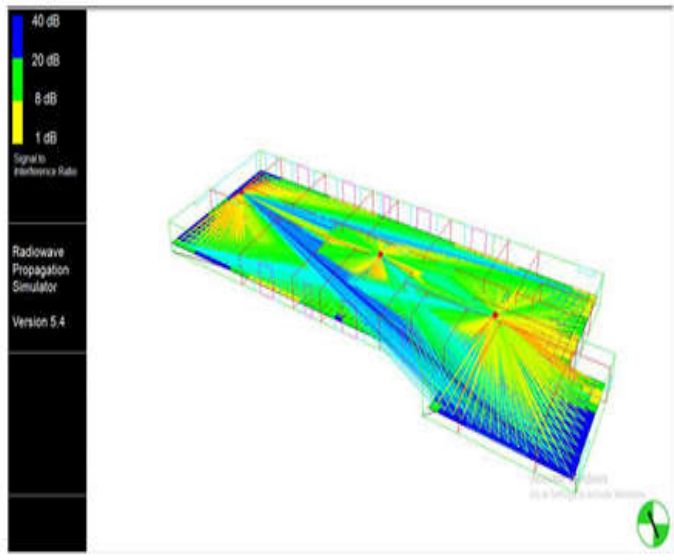

Gambar 7.c Tampilan coverage SIR 
Jurnal ECOTIPE, Volume 6, No.1, April 2019, Hal. 40-48

p-ISSN 2355-5068, e-ISSN 2622-4852

DOI: $10.33019 /$ ecotipe.v6i1.950

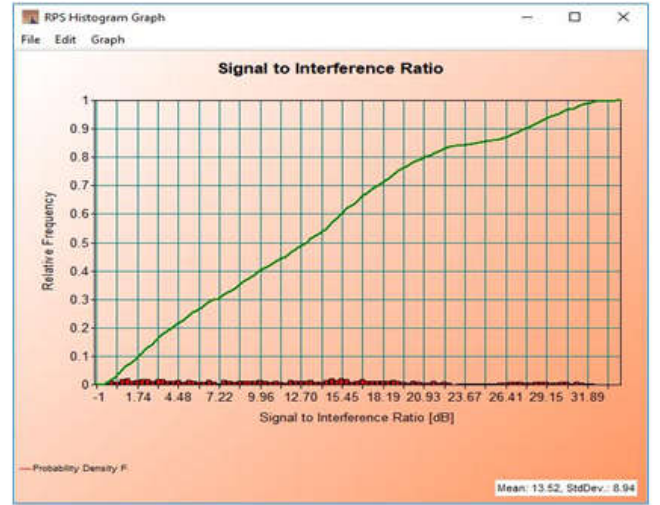

Gambar 7.d Tampilan diagram chart SIR

Untuk hasil coverage SIR menghasilkan mean 13,52 dB . Hasil ini masuk dalam kategori Baik yaitu antara $9 \mathrm{~dB}$ sampai $20 \mathrm{~dB}$.

\section{Hasil Simulasi Lantai 3}

Hasil simulasi dengan pemilihan penempatan FAP pada bagian tengah gedung terlihat pada Gambar 8.
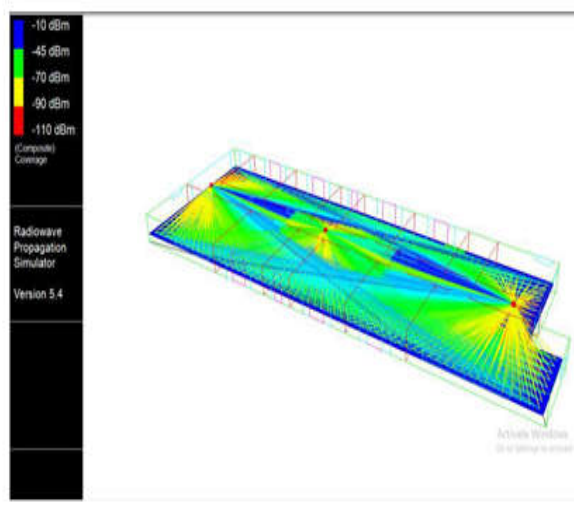

Gambar 8.a Tampilan coverage RSRP

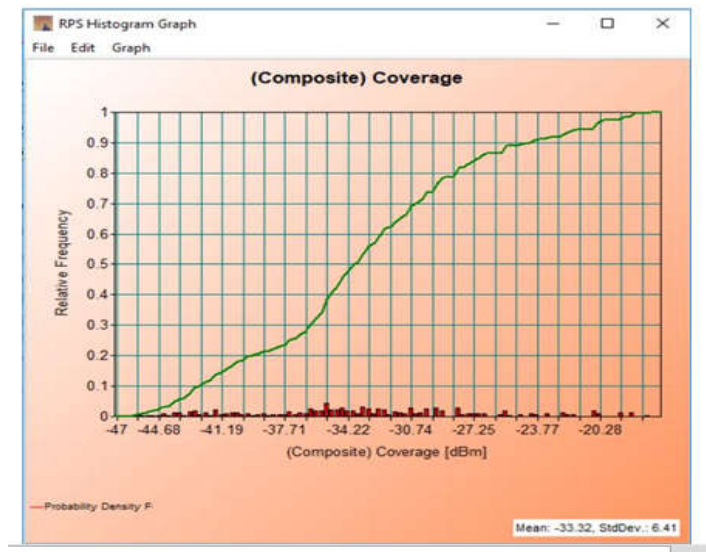

Gambar 8.b Tampilan diagram chart RSRP
Pada skenario ini coverage RSRP menghasilkan mean -33,32 dBm. Hasil ini masuk dalam kategori Sangat Baik yaitu antara -10 dBm sampai $-45 \mathrm{dBm}$

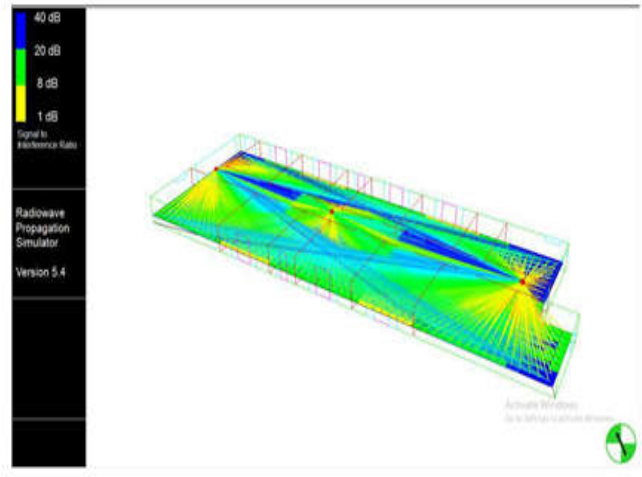

Gambar 8.c Tampilan coverage SIR

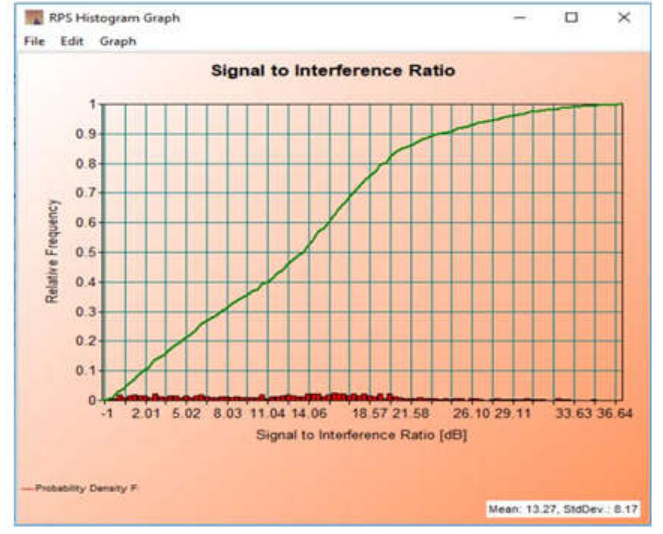

Gambar 8.d Tampilan diagram chart SIR

Untuk hasil coverage SIR menghasilkan mean 13,27 dB . Hasil ini masuk dalam kategori Baik yaitu antara $9 \mathrm{~dB}$ sampai $20 \mathrm{~dB}$.

4. Hasil Persentase Simulasi

Berikut hasil persentase simulasi RPS untuk parameter RSRP dan SIR. 
Jurnal ECOTIPE, Volume 6, No.1, April 2019, Hal. 40-48

p-ISSN 2355-5068, e-ISSN 2622-4852

DOI: $10.33019 /$ ecotipe.v6i1.950

Tabel 4. Nilai Persentase RSRP dan SIR Lantai 1

\begin{tabular}{|c|c|c|c|c|c|}
\hline \multicolumn{3}{|c|}{ RSRP } & \multicolumn{3}{|c|}{ SIR } \\
\hline Kategori & $\begin{array}{c}\text { Nilai } \\
(\mathrm{dBm})\end{array}$ & $\%$ & Kategori & $\begin{array}{l}\text { Nilai } \\
(\mathrm{dB})\end{array}$ & $\%$ \\
\hline $\begin{array}{l}\text { Sangat } \\
\text { Baik } \\
\end{array}$ & $\begin{array}{l}(-45)- \\
(-10)\end{array}$ & 99,80 & $\begin{array}{l}\text { Sangat } \\
\text { Baik }\end{array}$ & $(21)-(40)$ & 16,80 \\
\hline Baik & $\begin{array}{l}(-70)- \\
(-46)\end{array}$ & 0,20 & Baik & (9)-(20) & 47,47 \\
\hline Cukup & $\begin{array}{l}(-90)- \\
(-71)\end{array}$ & 0 & Cukup & (1)-(8) & 35,73 \\
\hline Buruk & $\begin{array}{l}(- \\
110)- \\
(-91)\end{array}$ & 0 & & & \\
\hline
\end{tabular}

Tabel 5. Nilai Persentase RSRP dan SIR Lantai 2

\begin{tabular}{|l|l|c|l|c|c|}
\hline \multicolumn{3}{|c|}{ RSRP } & \multicolumn{3}{c|}{ SIR } \\
\hline Kategori & $\begin{array}{c}\text { Nilai } \\
(d B m)\end{array}$ & $\%$ & Kategori & $\begin{array}{l}\text { Nilai } \\
(d B)\end{array}$ & $\%$ \\
\hline $\begin{array}{l}\text { Sangat } \\
\text { Baik }\end{array}$ & $\begin{array}{l}(-45)- \\
(-10)\end{array}$ & 97,98 & $\begin{array}{l}\text { Sangat } \\
\text { Baik }\end{array}$ & $\begin{array}{l}(21)- \\
(40)\end{array}$ & 20,81 \\
\hline Baik & $\begin{array}{l}(-70)- \\
(-46)\end{array}$ & 2,12 & Baik & $\begin{array}{l}(9)- \\
(20)\end{array}$ & 44,27 \\
\hline Cukup & $\begin{array}{l}(-90)- \\
(-71)\end{array}$ & 0 & Cukup & $(1)-(8)$ & 34,92 \\
\hline Buruk & $\begin{array}{l}(-110)- \\
(-91)\end{array}$ & 0 & & & \\
\hline
\end{tabular}

Tabel 6. Nilai Persentase RSRP dan SIR Lantai 3

\begin{tabular}{|l|c|c|l|c|c|}
\hline \multicolumn{3}{|c|}{ RSRP } & \multicolumn{3}{c|}{ SIR } \\
\hline Kategori & $\begin{array}{c}\text { Nilai } \\
\text { dBm })\end{array}$ & $\%$ & Kategori & $\begin{array}{c}\text { Nilai } \\
(d B)\end{array}$ & $\%$ \\
\hline $\begin{array}{l}\text { Sangat } \\
\text { Baik }\end{array}$ & $\begin{array}{l}(-45)- \\
(-10)\end{array}$ & 99,90 & $\begin{array}{l}\text { Sangat } \\
\text { Baik }\end{array}$ & $\begin{array}{c}(21)- \\
(40)\end{array}$ & 15,10 \\
\hline Baik & $\begin{array}{l}(-70)- \\
(-46)\end{array}$ & 0,10 & Baik & $\begin{array}{c}(9)- \\
(20)\end{array}$ & 52,65 \\
\hline Cukup & $\begin{array}{l}(-90)- \\
(-71)\end{array}$ & 0 & Cukup & & $(1)-(8)$ \\
\hline Buruk & $\begin{array}{l}(-110)- \\
(-91)\end{array}$ & 0 & & & 32,25 \\
\hline
\end{tabular}

Dari hasil simulasi menggunakan 3 FAP untuk setiap lantainya dengan penempatan pada sisi tengah gedung Elektronika terlihat untuk nilai masing-masing parameter RSRP dan SIR berada pada rentang nilai cukup sampai sangat baik sehingga dapat diterapkan dalam impelmentasi di lapangan.

\section{KESIMPULAN}

Dari uraian pembahasan yang dibuat pada perancangan jaringan indoor 4G LTE $1800 \mathrm{MHz}$ gedung Elektronika Politeknik Negeri Balikpapan dapat disimpulkan bahwa:

1. Berdasarkan perhitungan kapasitas user, dibutuhkan 3 Femtocell Access Point (FAP) untuk setiap lantai di gedung Elektronika.

2. Dengan desain pemilihan penempatan posisi FAP pada bagian sisi tengah di tiap lantainya hasil simulasi menunjukan nilai parameter RSRP dan SIR dalam kriteria kualitas cukup sampai Sangat Baik.

3. Pada lantai 1 , nilai rata-rata (mean) RSRP sebesar -32,18 dBm (sangat baik) dan nilai SIR sebesar 12,31 dB (baik).

4. Pada lantai 2 , nilai rata-rata (mean) RSRP sebesar -34,20 dBm (sangat baik) dan nilai SIR sebesar 13,52 dB (baik).

5. Pada lantai 3 , nilai rata-rata (mean) RSRP sebesar -33,32 dBm (sangat baik) dan nilai SIR sebesar 13,27 dB (baik)

\section{DAFTAR PUSTAKA}

[1] Pamungkas, G., A. (2012). Pengertian $1 G$, 4G, GSM, AMPS, CDMA dan WIMAX. wordpress.com/pengertian-1g-4g-gsmamps-cdma-dan-wimax, diakses 28 Okt 2012.

[2] Ulfah, M. (2016). Analisis Jumlah e Node B LTE untuk kota Balikpapan. Jurnal Sains Terapan. Politeknik Negeri Balikpapan Vol 2 No.1 halaman 56-59.

[3] Wardhana, L., dkk. (2014). 4G Handbook Edisi Bahasa Indonesia. www.nulisbuku.com, Jakarta.

[4] http://docplayer.info/29750704perancangan-jaringan-Indoor-4g-lte-tdd2300-mhz-menggunakan-radiowavepropagation-simulator.html.

[5] Hikmaturokhman, A., dkk. (2015). Analisa Model Propagasi COST 231 Multi Wall 
Jurnal ECOTIPE, Volume 6, No.1, April 2019, Hal. 40-48

p-ISSN 2355-5068, e-ISSN 2622-4852

DOI: $10.33019 /$ ecotipe.v6i1.950

pada Perancangan Jaringan Indoor

Femtocell HSDPA Menggunakan

Radiowave Propagartion Simulator. STTT

Telkom Purwokerto, Purwokerto.

[6] https://media.neliti.com/media/publications/

195491-ID-perancangan-dan-analisa-

penggelaran-lte.pdf

[7] https://edvanberliansa.wordpress.com/2016/

06/18/4g-lte-drive-test-parameter/ 